\title{
SST5 expression and USP8 mutation in functioning and silent corticotroph pituitary tumors
}

\author{
Solène Castellnou ${ }^{1,2}$, Alexandre Vasiljevic ${ }^{2,3,4}$, Véronique Lapras ${ }^{5}$, Véronique Raverot ${ }^{6}$, Eudeline Alix ${ }^{7}$, \\ Françoise Borson-Chazot ${ }^{1,2}$, Emmanuel Jouanneau ${ }^{2,4,8}$, Gérald Raverot ${ }^{1,2,4}$ and Hélène Lasolle ${ }^{1,2,4}$
}

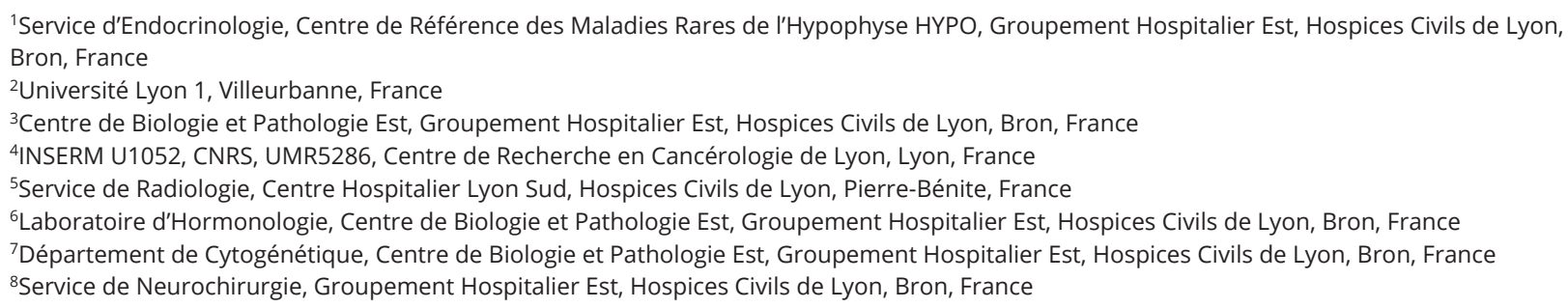

\begin{abstract}
Objective: Somatostatin receptor type 5 (SST5) is inconsistently expressed by corticotroph tumors, with higher expression found in corticotropinomas having ubiquitin-specific protease 8 (USP8) mutations. Aims were to study the correlation between characteristics of corticotropinomas and SST5 expression/USP8 mutation status and to describe the response to pasireotide in five patients.

Design: Retrospective cohort study.

Methods: Clinico-biochemical, radiological and pathological data of 62 patients, operated for a functioning or silent corticotropinoma between 2013 and 2017, were collected. SST5 expression was measured by immunohistochemistry (clone UMB-4, Abcam, IRS > 1 being considered positive), and Sanger sequencing was performed on 50 tumors to screen for USP8 mutations.

Results: SST5 expression was positive in 26/62 pituitary tumors. A moderate or strong IRS was found in 15/58 corticotropinomas and in 13/35 functioning corticotropinomas. Among functioning tumors, those expressing SST5 were more frequent in women (22/24 vs $9 / 15, P=0.04)$ and had a lower grade $(P=0.04)$ compared to others. USP8 mutations were identified in 13/50 pituitary tumors and were more frequent in functioning compared to silent tumors (11/30 vs $2 / 20, P=0.05)$. SST5 expression was more frequent in USP8mut vs USP8wt tumors (10/11 vs $7 / 19, P=0.007)$. Among treated patients, normal urinary free cortisol levels were obtained in three patients (IRS 0, 2 and 6), while a fourfold decrease was observed in one patient (IRS 4).

Conclusion: SST5 expression appears to be associated with functioning, USP8mut and lower grade corticotropinomas. A correlation between SST5 expression or USP8mut and response to pasireotide remains to be confirmed.
\end{abstract} Key Words

- SST5

- corticotroph pituitary tumors

- USP8 


\section{Introduction}

Cushing's disease is a rare disorder defined as chronic hypercortisolism due to a corticotropin-secreting pituitary tumor (corticotroph tumor) (1). Chronic cortisol excess is responsible for multisystem morbidity, contributing to increased mortality and altered quality of life $(2,3)$. In some cases, corticotroph tumors are discovered during examination or analyses in patients showing no clinical signs of Cushing's disease and these are termed silent corticotroph tumors. Diagnosis of such tumors arises because of symptoms related to tumor mass, symptoms of hyperprolactinemia or pituitary deficiency, and they are often classified as non-functioning pituitary tumors (4, 5). Treatment of Cushing's disease is obligatory in order to control cortisol excess and to prevent morbi-mortality. Transsphenoidal surgical resection is the first-line treatment with a remission rate of approximately $75 \%$ when the surgery is performed by an expert pituitary surgeon $(6,7$, $8)$. However, recurrence occurs in 15 to $66 \%$ of patients and some patients either refuse or do not benefit from the surgery (7). Alternative treatments include additional pituitary surgery, radiation therapy or medical treatment $(9,10)$. Medical treatments can be divided into the use of drugs that block cortisol production (anticortisolic drugs) or block cortisol action (glucocorticoid receptor blockers), which do not control pituitary tumor growth and secretion, and those treatments that target the corticotroph tumor (cabergoline or pasireotide). Pasireotide, a secondgeneration somatostatin analog, acting on somatostatin receptor (SST) subtype 1,2,3 and 5, is the only approved pituitary-targeting drug for the treatment of Cushing's disease $(11,12,13,14,15)$. Its efficacy is variable. In phase III studies, 24-h urinary free cortisol (24-h UFC) was reported to be normalized in 20 to $40 \%$ of patients after 6 months of treatment; however, it was associated with numerous side-effects including hyperglycemia and diabetes mellitus $(13,14)$. Predictive markers of response to pasireotide are, however, lacking as has been already been reported to be the case in somatrotroph tumors, though an association between the expression of somatostatin receptor subtypes, in particular SST5, and response to treatment has been suggested (16). Most published studies have quantified SST5 mRNA expression in corticotroph tumors using quantitative RT-PCR and reported its expression in 80 to $100 \%$ of tumors (12, 17, 18, 19). However, using immunohistochemistry (IHC), SST5 expression was only found in 20 to $55 \%$ of corticotroph tumors $(20,21,22)$. Somatic driver mutations in the ubiquitin-specific protease 8
(USP8) gene, identified in $35 \%$ to $60 \%$ of corticotroph tumors $(21,23,24,25,26,27,28)$, lead to an increase in the deubiquitinase activity of USP8 and to an increase of ACTH secretion by the tumor (28). SST5 expression has been found to be higher in USP8mut corticotroph tumors (21). The increased SST5 expression in USP8 mutated tumors suggests a positive response to pasireotide in those tumors. The prognosis associated with those mutations is controversial, as they seem to be associated with a greater likelihood of surgical remission (23) as well as a higher risk of recurrence of Cushing's disease (24).

The goal of the present study was to characterize SST5 IHC expression and USP8 mutations in a large cohort of functioning and silent corticotroph pituitary tumors and to correlate its expression with clinical and biochemical characteristics of patients at diagnosis. Additionally, SST5 expression and response to pasireotide was studied in five patients.

\section{Materials and methods}

\section{Patients and assessments}

Between January 2013 and December 2017, 76 patients underwent surgery for a corticotroph tumor at the neurosurgical service of University Lyon Hospitals (Hospices Civils de Lyon) carried out by one expert neurosurgeon (E J). Six patients operated for recurrence, without access to initial pathology, were excluded from the study, and eight patients were excluded because of insufficient material being obtained to perform SST5 IHC. Initial clinical presentation data, including sex and age at surgery, preoperative hormonal assessment and pituitary MRI, were collected. Five patients were pre-treated with anticortisolic drugs before their surgery, either by ketoconazole $(n=4)$ or mitotane $(n=1)$. Corticotroph tumors were reported as silent when no clinical or biochemical signs of Cushing's disease were present prior to surgery. Preoperative MRI were reviewed by a pituitary specialist radiologist $(\mathrm{V} L)$, and the tumor size, defined as the largest diameter observed on MRI, and cavernous sinus invasion (according to Knosp's classification (29)) were both noted.

The response to pasireotide was studied retrospectively in five treated patients operated for a corticotroph tumor at Lyon Hospital between 2010 and 2018. Patients with combined medical treatment of hypercortisolism were excluded. Initial 24-h-UFC levels were compared with those during and at the end of the treatment, and clinical improvement as well as any side-effects were reported.

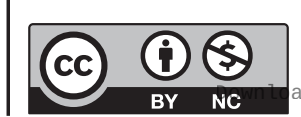


The study was approved by the ethics committee of Hospices Civils de Lyon. Consent was obtained from each patient or subject after full explanation of the purpose and nature of all procedures used. Patient information was recorded in a local database (PITUICARE-Lyon, registered with the French data protection agency CNIL, 16-021, and clinicaltrials.org, NCT 02854228).

\section{Biochemistry}

Cortisol and ACTH measurements were performed using automated immunoassays (Roche Diagnostics). For cortisol assays, inter-assay CVs were $1.9 \%$ at the $109 \mathrm{nmol} / \mathrm{L}$ level, $2.8 \%$ at the $333 \mathrm{nmol} / \mathrm{L}$ level and $2.8 \%$ at the $741 \mathrm{nmol} / \mathrm{L}$ level. For ACTH, inter-assay CVs were $9.2 \%$ at the $20 \mathrm{ng} / \mathrm{L}$ level, $2.1 \%$ at the $52 \mathrm{ng} / \mathrm{L}$ level and $2.3 \%$ at the $925 \mathrm{ng} / \mathrm{L}$ level. 24-h UFC was measured with a direct competitive immunoassay (Abbott Diagnostics). Inter-assay CVs were $3.6 \%, 3.9 \%, 2.2 \%$ and $3.2 \%$ at concentrations of $124.0 \mathrm{nmol} / \mathrm{L}, \quad 273.2 \mathrm{nmol} / \mathrm{L}, \quad 465.6 \mathrm{nmol} / \mathrm{L}$ and $1035.1 \mathrm{nmol} / \mathrm{L}$, respectively. Data for 24 -h UFC were missing in 19 cases, including 15 silent corticotroph pituitary tumors. In accordance with the French Society of Endocrinology guidelines, biochemical exploration of the corticotroph axis was performed in clinically non-functioning pituitary tumors to screen for corticotroph deficiency and to exclude potential silent corticotroph tumors (30).

\section{Pathology}

All tumors $(n=62)$ were stained for ACTH, SST5, Ki67 and p53 using IHC and were assessed by a single experienced pathologist (A V) who was blinded to the clinical data. Immunohistochemical analysis was performed on 4- $\mu$ m paraffin sections using the BenchMark ${ }^{\circledR}$ ULTRA automated immunostainer (Ventana Medical Systems Inc, Tucson, AZ, USA) and the following antibodies and dilutions: anti-ACTH (clone AH26, 1:300, Diagnostic Biosystems, Pleasanton, CA, USA), anti-SST5 (clone UMB-4, 1:250, Abcam), anti-Ki67 (clone MIB1, 1:100, Dako) and anti-p53 (clone D07, 1:100, Dako). SST5 immunohistochemistry required an additional amplification step (amplification kit, Ventana Medical Systems). To evaluate the expression of SST5, only membrane immunopositivity was considered (inter-endothelial junctional immunopositivity served as an internal positive control). SST5 immunopositivity was scored according to the IRS scoring system (Supplementary Table 1, see section on supplementary materials given at the end of this article). As defined by IRS classification, the staining was considered to be negative for IRS 0 and 1 and positive for IRS $>1$. Four tumors were considered SST5-positive despite the IRS being not evaluable, as the size of the removed tumor was insufficient to precisely assess the percentage of positive cells. The percentage of ACTH-positive cells and granular and strongly basophilic staining of the cytoplasm were analyzed as indicators of corticotroph tumor differentiation. Proliferation markers (mitotic activity, immuno-expression of p53 and Ki67) were also analyzed. A clinico-pathological classification was applied according to Trouillas et al. (29). This classification takes into account cavernous and/or sphenoid sinus invasion and the presence of proliferative markers (presence of at least two out of the three following features: more than two mitotic figures, positive expression of p53 or Ki67-positive cells superior or equal to $3 \%$ ). In six patients, grading was not feasible because of the small size of the tumoral tissue.

\section{Molecular analysis}

USP8 analysis was performed in 50 tumors, while analysis could not be conducted in 12 tumors because of the lack of tumor tissue. Genomic DNA was extracted from formalin-fixed, paraffin-embedded tissue sections using the Maxwell RSC FFPE DNA Kit (AS1450). The DNA sequence was amplified by PCR with the CORE 10 (Mpbio) NH4(SO4)2 Kit (MP Biomedicals, Irvine, CA, USA) using the forward primer 5'-CACCCCTCCAACTCATAAAG-3' and reverse primer 5'-GTTCTAGGAGTTAAGATAAACATAC-3'. Sanger sequencing of PCR products was performed on the ABI 3500 Dx Analyzer (Applied Biosystems) after having employed the BigDye ${ }^{\text {TM }}$ Terminator v3.1 Cycle Sequencing Kit (Applied Biosystems). Results were interpreted with Seqscape Version3 software. In seven complicated cases with results that were difficult to interpret, TOPO cloning was performed after PCR amplification using the TOPO ${ }^{\circledR}$ TA Cloning® Kit (Invitrogen). PCR, sequencing and analyses were carried out following the same protocols.

\section{Statistical analysis}

Data are presented as median and ranges (minimum and maximum). The association between SST5 expression (negative or positive) or USP8 mutations (wild type or mutant) and patient/tumor characteristics were tested using Fisher's exact test for qualitative data and Wilcoxon rank test for quantitative data. Statistical analyses were performed using R software version 3.3.0 (www.r-project. org/). $P$-values $<0.05$ were considered as significant.

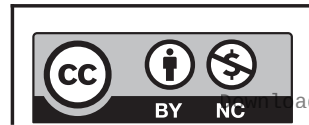




\section{Results}

\section{Cohort description}

The study population consisted of $62(44 \mathrm{~F} / 18 \mathrm{M})$ patients who were evaluated retrospectively. Patient characteristics are described in Table 1. The median tumor size was $11.5 \mathrm{~mm}$ with three tumors that were not visible on MRI which were operated after inferior petrosal sinus sampling. Overall, 26/62 tumors were SST5-positive. Eight different USP8 mutations were detected in 13 out of the 50 tumors, and one mutation (Ser719del) was found in 7 of the 13 patients (Supplementary Table 2). Of the 62 patients in our cohort, 23 with neither clinical nor biochemical hypercortisolism were diagnosed postoperatively as having silent corticotroph tumors (Table 1).
Patients with silent corticotroph tumors were older than those with functioning corticotroph tumors $(P$-value $=0.03)$. Although 24 -h UFC and $08: 00 \mathrm{~h}$ cortisol were lower in silent tumors (both $P$-values $<0.001$ ), $08: 00 \mathrm{~h}$ ACTH levels were similar at diagnosis $(P$-value $=0.41)$. While 26/39 functioning corticotroph tumors were microadenomas, silent corticotroph pituitary tumors were mostly macroadenomas (only one was a microadenoma), with a larger diameter (both $P$-value $<0.001$ ), and were more often invasive and positive for p53 (both $P$-values $=0.05$ ). Silent corticotroph tumors were less differentiated, with a lower percentage of ACTH expression ( $P$-value $<0.001$, Fig. 1). SST5 expression and USP8 mutations were less frequent in silent tumors compared to functioning corticotroph tumors ( $P$-value $<0.001$ and 0.05$)$.

Table 1 Clinical, radiological and pathological features of 62 patients operated for corticotroph tumors, categorized by functional characteristics.

\begin{tabular}{|c|c|}
\hline & All patients \\
\hline & $n=62$ \\
\hline Sex ratio F/M & $44 / 18$ \\
\hline Age at surgery (years), median (range) & $44(11-75)$ \\
\hline Cortisol 08:00 h (nmol/L), median (range) & $\begin{array}{c}496(227-1191) \\
N A=5\end{array}$ \\
\hline ACTH 08:00 h (ng/L), median (range) & $\begin{array}{c}50(15-204) \\
N A=10\end{array}$ \\
\hline 24-h UFC (nmol/24 h), median (range) & $\begin{array}{c}377(49-8657) \\
N A=19\end{array}$ \\
\hline Macro adenomas & 35 \\
\hline Size on MRI (mm), median (range) & $\begin{array}{c}11.5(0-70) \\
N A=1\end{array}$ \\
\hline Invasive corticotroph tumor & 20 \\
\hline SST5 positive & 26 \\
\hline $\begin{array}{l}\text { IRS categories } \\
\text { Negative }\end{array}$ & 36 \\
\hline Mild & 7 \\
\hline Moderate & 12 \\
\hline Strongly positive & $\begin{array}{c}3 \\
N A=4\end{array}$ \\
\hline ACTH expression (\%), median (range) & $\begin{array}{c}100(5-100) \\
N A=1\end{array}$ \\
\hline $\mathrm{Ki} 67 \geq 3 \%$ & $\begin{array}{c}12 \\
N A=6\end{array}$ \\
\hline Mitosis> 2 & $\begin{array}{c}5 \\
N A=4\end{array}$ \\
\hline Positive P53 expression & $\begin{array}{c}12 \\
N A=5\end{array}$ \\
\hline Grade & $\begin{aligned} 1 a & =34 \\
1 b & =4 \\
2 a & =17 \\
2 b & =1 \\
N A & =6\end{aligned}$ \\
\hline USP8 mutations & $\begin{array}{c}13 \\
N A=12\end{array}$ \\
\hline
\end{tabular}

\begin{tabular}{c}
\hline Functioning \\
\hline$n=39$ \\
\hline $31 / 8$ \\
$40(11-73)$ \\
$531(297-1191)$ \\
$N A=2$ \\
$55(15-204)$ \\
$N A=3$ \\
$620(102-8657)$ \\
$N A=4$ \\
13 \\
$7(0-50)$ \\
9 \\
24 \\
15 \\
7 \\
10 \\
3 \\
$N A=4$ \\
$100(30-100)$ \\
10 \\
$N A=5$ \\
4 \\
$N A=4$ \\
4 \\
$N A=5$ \\
$1 a=23$ \\
$1 b=3$ \\
$2 a=7$ \\
$2 b=1$ \\
$N A=5$ \\
11 \\
$N A=9$ \\
\\
\\
\\
$N$ \\
$N$
\end{tabular}

\begin{tabular}{|c|c|}
\hline Silent & \\
\hline$n=23$ & $P$-value ${ }^{a}$ \\
\hline $13 / 10$ & 0.08 \\
\hline $50(22-75)$ & 0.03 \\
\hline 376 (227-808) & $<0.001$ \\
\hline$N A=3$ & \\
\hline $45(16-126)$ & 0.41 \\
\hline$N A=7$ & \\
\hline 96 (49-207) & $<0.001$ \\
\hline $\mathrm{NA}=15$ & \\
\hline 22 & $<0.001$ \\
\hline $23.8(7-70)$ & $<0.001$ \\
\hline$N A=1$ & \\
\hline 11 & 0.05 \\
\hline 2 & $<0.001$ \\
\hline 21 & 0.001 \\
\hline 0 & \\
\hline 2 & \\
\hline 0 & \\
\hline $93(5-100)$ & $<0.001$ \\
\hline$N A=1$ & \\
\hline 2 & 0.1 \\
\hline$N A=1$ & \\
\hline 1 & 0.64 \\
\hline 8 & 0.05 \\
\hline $1 a=11$ & 0.18 \\
\hline $1 b=1$ & \\
\hline $2 a=10$ & \\
\hline $2 b=0$ & \\
\hline$N A=1$ & \\
\hline 2 & 0.05 \\
\hline$N A=3$ & \\
\hline
\end{tabular}

${ }^{a}$ Calculated using Fisher exact test and Wilcoxon rank test. 24-h FC, 24-h urinary free cortisol; NA, data not available.

https://ec.bioscientifica.com https://doi.org/10.1530/EC-20-0035 (c) 2020 The authors Published by Bioscientifica Ltd

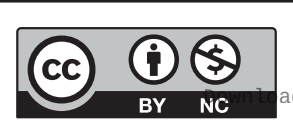

This work is licensed under a Creative Commons Attribution-NonCommercial 4.0 International License. ded from Bioscientifica.com at $04 / 26 / 2023$ 04:58:35AM via free access 


\section{Silent corticotroph tumors}

Out of the 23 silent tumors, only two were SST5 positive, both with a moderate IRS. USP8 analyses were performed in 20 tumors and two patients had mutations, both of these being Ser719del (Fig. 2 and Supplementary Table 2). Only one patient simultaneously showed positive SST5 expression and a USP8 mutation. Among these three patients, with either USP8 mutation or a positive SST5 expression or both, all were women, aged 16 to 75 years old. All tumors were grade 1 a macroadenomas, with sizes varying from 11.5 to $21 \mathrm{~mm}$.

Due to the small number of patients that were SST5postive or showed USP8 mutations, no comparisons could be made based on SST5 expression or USP8 mutations.

\section{Functioning corticotroph tumors}

\section{SST5 expression}

Markers associated with SST5 expression were studied in the 39 functioning corticotroph tumors (Table 2). Among these, 24 of the patients were SST5-positive and 15 were SST5-negative. Positive SST5 expression was more frequent in women $(22 / 24$ vs $9 / 15, P$-value $=0.04)$. Although the grade was found to be lower in SST5-positive tumors $(P$-value $=0.04)$, invasion was not statistically different for all functioning tumors but a difference was found in the subgroup of macroadenomas. Indeed, SST5positive macroadenomas were less invasive than SST5negative macroadenomas $(4 / 24$ vs $5 / 15, P=0.03)$. USP 8 mutations were more frequent in SST5-positive tumors $(10 / 17$ vs $1 / 13, P$-value $=0.007)$. The only significant difference between SST5-positive and SST5-negative functioning microadenomas was patient age, as patients with SST5-positive tumors were significantly older

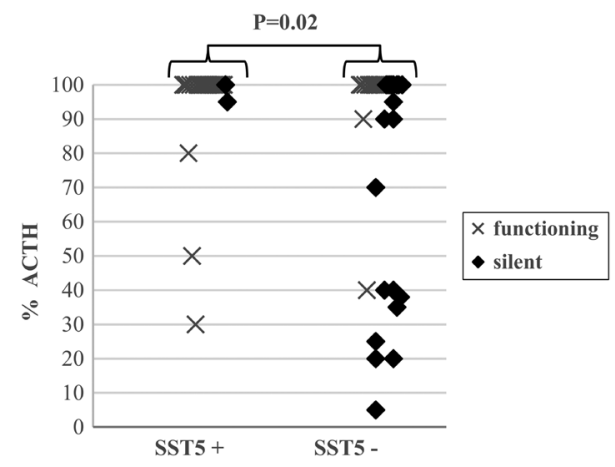

Figure 1

ACTH expression in SST5 positive and negative corticotroph tumors according to the functional status. $P$-value calculated using Wilcoxon rank test.

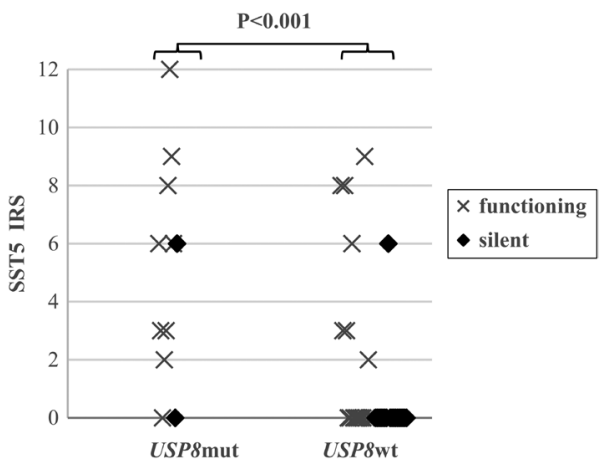

Figure 2

SST5 expression in USP8mut or USP8wt corticotroph tumors. mut, mutant; wt, wild-type. $P$-value calculated using Wilcoxon rank test.

(46 vs 29 years, $P$-value $=0.01$ ). Among patients pre-treated by anticortisolic drugs, only one patient pre-treated with ketoconazole had a significant SST5 expression (IRS 6).

\section{USP8 mutations}

Among the 20 functioning tumors in which USP8 sequencing was performed, 11 had USP8 mutations (Table 3). USP8mut corticotroph tumors were more often SST5 positive $(10 / 11$ vs $7 / 19, P$-value $=0.007)$ and had a higher IRS $(P$-value $=0.04)$ compared to USP8wt, while no other significant differences were found for other characteristics.

\section{Response to pasireotide treatment}

The evolution of 24-h UFC of five patients treated by pasireotide, as well as their IHC results, are presented in Fig. 3. SST5 expression was negative in patient A (IRS 0), while it was positive in four cases with an IRS of 2, 4, 6 and 8 respectively (in patients B, C, D and E). Patients $\mathrm{B}, \mathrm{D}$ and $\mathrm{E}$ were treated due to recurrence of Cushing's disease, occurring between 2 and 6 years after surgery, while patients $\mathrm{A}$ and $\mathrm{C}$ were treated prior to their pituitary surgery. In all patients, treatment was introduced at a dose of $0.6 \mathrm{mg}$ twice a day. In one patient, the dosage was increased but then rapidly reduced because of digestive side-effects (diarrhea). At the end of treatment, three (A, B and D) out of five patients had a normal 24-h UFC, while a significant change (four-fold decrease) in 24-h UFC was observed in patient C. Clinical improvement of Cushing's symptoms during pasireotide treatment was observed in all cases. Side-effects were frequent with all patients suffering from digestive disorders, while disturbed blood glucose in patients with pre-existing diabetes was observed in four patients and diabetes was newly diagnosed in one patient.

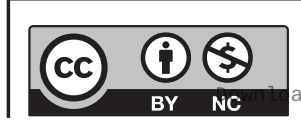

This work is licensed under a Creative Commons Attribution-NonCommercial 4.0 International License. ded from Bioscientifica.com at 04/26/2023 04:58:35AM 
Table 2 Clinical, radiological and pathological features in functioning corticotroph tumors based on SST5 expression $(n=39)$.

\begin{tabular}{|c|c|c|c|}
\hline & SST5 + & SST5 - & \\
\hline & $n=24$ & $n=15$ & P-value $^{a}$ \\
\hline Sex ratio F/M & $22 / 2$ & $9 / 6$ & 0.04 \\
\hline Age (years), median (range) & $43(22-73)$ & $33(11-67)$ & 0.09 \\
\hline Cortisol 08:00 h (nmol/L), median (range) & $\begin{array}{c}559(319-1191) \\
N A=1\end{array}$ & $\begin{array}{c}513(297-978) \\
N A=1\end{array}$ & 0.25 \\
\hline ACTH 08:00 h (ng/L), median (range) & $\begin{array}{c}59(16-136) \\
N A=2\end{array}$ & $\begin{array}{c}46(15-204) \\
N A=1\end{array}$ & 0.49 \\
\hline 24-h UFC (nmol/24 h), median (range) & $\begin{array}{c}620(102-8657) \\
N A=3\end{array}$ & $\begin{array}{c}479(145-2300) \\
N A=1\end{array}$ & 0.78 \\
\hline Macroadenomas & 8 & 5 & 1 \\
\hline Size on MRI (mm), median (range) & $7(0-22)$ & $7(0-50)$ & 0.65 \\
\hline Invasive corticotroph tumor & 4 & 5 & 0.27 \\
\hline ACTH expression (\%), median (range) & $100(30-100)$ & $100(40-100)$ & 1 \\
\hline $\mathrm{Ki} 67 \geq 3 \%$ & $\begin{array}{c}6 \\
N A=2\end{array}$ & $\begin{array}{c}4 \\
N A=3\end{array}$ & 0.71 \\
\hline Mitosis $>2$ & $\begin{array}{c}3 \\
N A=1\end{array}$ & $\begin{array}{c}1 \\
N A=3\end{array}$ & 1 \\
\hline Positive P53 expression & $\begin{array}{c}1 \\
N A=2\end{array}$ & $\begin{array}{c}3 \\
N A=3\end{array}$ & 0.12 \\
\hline Grade & $\begin{aligned} 1 a & =18 \\
1 b & =1 \\
2 a & =2 \\
2 b & =1 \\
N A & =2\end{aligned}$ & $\begin{aligned} 1 a & =5 \\
1 b & =2 \\
2 a & =5 \\
2 b & =0 \\
N A & =3\end{aligned}$ & 0.04 \\
\hline USP8 mutations & $\begin{array}{c}10 \\
N A=7\end{array}$ & $\begin{array}{c}1 \\
N A=2\end{array}$ & 0.007 \\
\hline
\end{tabular}

${ }^{a}$ Calculated using Fisher exact test and Wilcoxon rank test. 24-h UFC, 24-h urinary free cortisol; NA, data not available.

The reasons for the interruption of treatment were: digestive side-effects and no decrease in tumor volume in patient A, poor observance and difficulty of monitoring for patient $B$, pituitary surgery in patient $C$, hepatic cytolysis (five-fold increase in transaminases) and the appearance of gallstones in patient $\mathrm{D}$ and bilateral adrenalectomy in patient E.

\section{Discussion}

In our cohort of 62 patients, more than one-third of corticotroph pituitary tumors were silent tumors, clinically classified as nonfunctioning pituitary tumors but reclassified after pathology analysis as corticotroph tumors. Overall, USP8 mutations were found in 13/50 tumors and SST5 was expressed in 26/62 tumors, results which are in accordance with previous findings $(20,21,22,23,24,25,26,27,28)$. Compared to silent tumors, functioning tumors more frequently showed USP8 mutations and positive SST5 expression, with about one-third expressing SST5 receptor with an IRS either moderate or strong. Our results demonstrated an association between the presence of USP8 mutation and SST5 expression among functioning tumors. Moreover, functioning corticotroph tumors expressing SST5 were more frequent in women and had a significantly lower grade on clinicopathological classification, suggestive of a better prognosis.

The value of SST5 expression studied by IHC in predicting the response to pasireotide is unknown in corticotroph tumors. In somatotroph pituitary tumors, pasireotide has been shown to decrease GH secretion in vivo and in vitro and to reduce tumor volume $(31,32,33)$, with an efficacy which seems to be correlated to SST5 expression (16). In lactotroph pituitary tumors, pasireotide was recently reported to be effective in a few cases of tumors that were resistant to dopamine agonists and expressed SST5, producing biochemical control and either stabilization or reduction in tumor volume (34, $35,36)$. One limiting factor in the evaluation of the role of SST5 is the interpretation of its expression using IHC. The intensity of SST5 expression can be evaluated using different scoring systems, which sometimes take into account cytoplasmic-positivity $(16,22,37)$. We chose to consider only membrane immunopositivity and,
This work is licensed under a Creative Commons Attribution-NonCommercial 4.0 International License. ded from Bioscientifica.com at 04/26/2023 04:58:35AM via free access 
Table 3 Clinical, radiological and pathological features in functioning corticotroph tumors based on the presence of USP8 mutations $(n=30)$

\begin{tabular}{|c|c|c|c|}
\hline & USP8mut & USP8wt & \\
\hline & $n=11$ & $n=19$ & P-value $^{a}$ \\
\hline Sex ratio F/M & $10 / 1$ & $14 / 5$ & 0.37 \\
\hline Age (years), median (range) & $41(22-73)$ & $37(11-67)$ & 0.64 \\
\hline Cortisol 08:00 h (nmol/L), median (range) & $\begin{array}{c}547(366-922) \\
\quad N A=1\end{array}$ & $\begin{array}{c}531(297-1191) \\
N A=1\end{array}$ & 0.76 \\
\hline ACTH 08:00 h (ng/L), median (range) & $\begin{array}{c}55(16-119) \\
N A=1\end{array}$ & $\begin{array}{c}54(15-204) \\
N A=2\end{array}$ & 0.84 \\
\hline 24-h UFC (nmol/24 h), median (range) & $\begin{array}{c}214(10-8657) \\
N A=1\end{array}$ & $\begin{array}{c}465(145-2300) \\
N A=2\end{array}$ & 0.26 \\
\hline Macroadenomas & 5 & 7 & 0.71 \\
\hline Size on MRI (mm), median (range) & $8(7-22)$ & $7(0-50)$ & 0.18 \\
\hline Invasive corticotroph tumor & 2 & 5 & 1 \\
\hline SST5 positive & 10 & 7 & 0.007 \\
\hline \multicolumn{4}{|l|}{ IRS categories } \\
\hline Negative & 1 & 12 & 0.04 \\
\hline Mild & 3 & 3 & \\
\hline Moderate & 3 & 3 & \\
\hline Strongly positive & 2 & 1 & \\
\hline & $N A=2$ & & \\
\hline ACTH expression (\%), median (range) & $100(30-100)$ & $100(40-100)$ & 0.54 \\
\hline $\mathrm{Ki} 67 \geq 3 \%$ & 3 & $\begin{array}{c}5 \\
N A=2\end{array}$ & 1 \\
\hline Mitosis $>2$ & 3 & $\begin{array}{c}1 \\
N A=2\end{array}$ & 0.27 \\
\hline Positive P53 expression & 2 & $\begin{array}{c}1 \\
N A=2\end{array}$ & 0.54 \\
\hline Grade & $\begin{array}{l}1 a=7 \\
1 b=2 \\
2 a=1 \\
2 b=1\end{array}$ & $\begin{aligned} 1 a & =12 \\
1 b & =0 \\
2 a & =5 \\
2 b & =0 \\
N A & =2\end{aligned}$ & 0.09 \\
\hline
\end{tabular}

${ }^{a}$ Calculated using Fisher exact test and Wilcoxon rank test.

24-h UFC, 24-h urinary free cortisol; NA, data not available; mut, mutant; wt, wild-type.

after comparison of SST5-positive and -negative tumors, to use the IRS scoring system in order to more precisely evaluate SST5 expression. This methodology has been employed in previous studies to assess SST expression in pituitary tumors $(21,38,39)$, which allowed a more reliable comparison between studies.

In functioning corticotroph tumors, pasireotide is indicated in order to decrease hypercortisolism. In vitro studies on corticotroph tumor cells have found a decrease in ACTH release following use of pasireotide, which seems to be mediated by SST5 $(12,17,40,41,42)$. Indeed, SST5 is the most highly expressed somatostatin receptor in corticotroph tumors $(12,20,42)$, and it has been shown in previous studies that octreotide, which targets SST2, is less effective than pasireotide in decreasing cortisol levels and that SST2 is downregulated in the context of exposure to high glucocorticoid levels $(41,42)$. The response rate to pasireotide treatment in Cushing's disease obtained in previously published clinical trials was between 20 to $40 \%(13,14)$, which is in agreement with the number of patients with functioning corticotroph tumors expressing SST5 with an IRS score of moderate or strong in our cohort, suggesting that only one-third of functioning corticotroph pituitary tumors are likely to be sensitive to pasireotide treatment. In our study, functioning tumors that were SST5-positive had a lower grade and probably a lower risk of recurrence, suggesting that these tumors are less likely to require pasireotide treatment. However, it has been previously reported that USP8mut tumors had a higher risk of recurrence (24). The correlation between the expression of SST5 in corticotroph tumors and the efficacy of pasireotide is lacking. Unfortunately, only five patients operated for a corticotroph tumor in Lyon between 2010 and 2018 were treated with pasireotide monotherapy, without combined medical treatment of their hypercortisolism. Four patients expressed SST5, https://ec.bioscientifica.com

https://doi.org/10.1530/EC-20-0035 (c) 2020 The authors Published by Bioscientifica Ltd
This work is licensed under a Creative Commons Attribution-NonCommercial 4.0 International License. ded from Bioscientifica.com at 04/26/2023 04:58:35AM via free access 
A

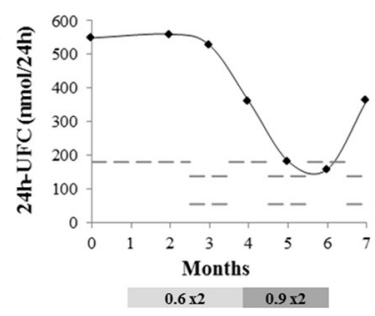

B

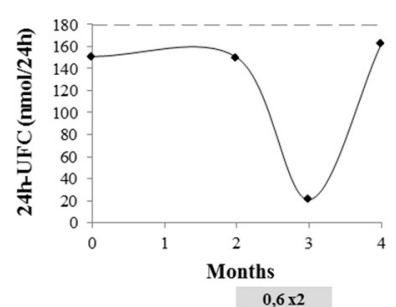

C

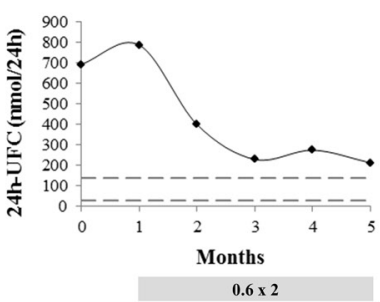

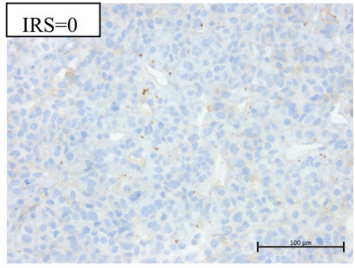
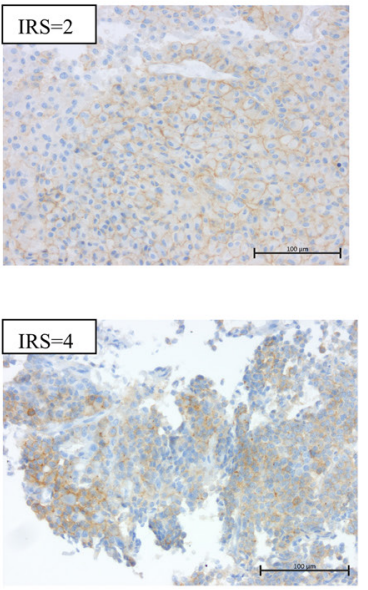

$\mathrm{D}$
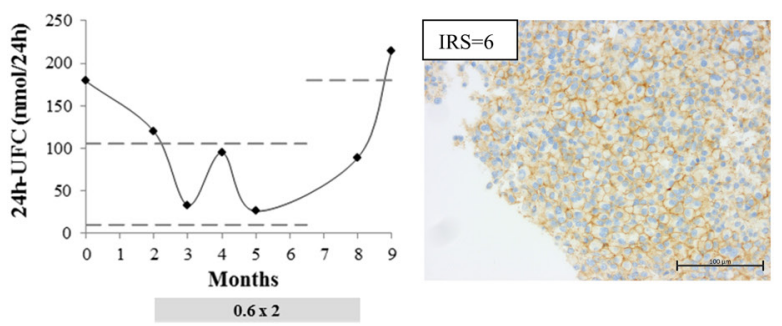

E
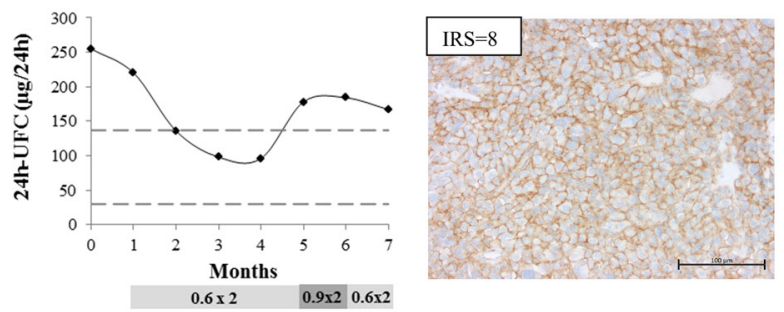

Figure 3

Evolution of 24-h UFC after introduction of pasireotide in patients A to E (left) and SST5 immunohistochemistry (original magnification $\times 200$ ) (right). 24-h UFC, 24-h urinary free cortisol; IRS, immunoreactive score. Dotted lines on graphs represent 24-h-UFC norm, and daily dosage of pasireotide is represented below each graph, expressed in mg. Photographs were taken in the most immunoreactive area and are not representative of the whole tumor.

one patient showed mild expression and three patients had moderate expression. Though an improvement of hypercortisolism and of Cushing's symptoms was observed in most of the patients, including those that were SST5-negative, the small number of patients and the difference in duration of treatment do not allow us to reach firm conclusions. Pasireotide was used in preoperative treatment, showing a good response in two patients, with an IRS of 0 and 4 . It has been reported that preoperative octreotide treatment can result in decreased SST2 expression. SST trafficking is modulated by pasireotide in a different manner than its modulation by octreotide $(40,43)$. However, as the effect of preoperative treatments on SST5 is not yet well understood, it is not possible to exclude a decrease in SST5 expression following pasireotide treatment.

In previous in vitro and in vivo studies, pasireotide has also been associated with an anti-tumoral effect (12, 44, $45,46)$. A recent publication reporting the use of longacting pasireotide demonstrated that median tumor volume decreased by $17.8 \%$ and $16.3 \%$, respectively, after 12 months of treatment with pasireotide at 10 or $30 \mathrm{mg} / \mathrm{month}$ in patients with Cushing's disease (14).
However, the role of SST5 in this anti-tumoral effect is controversial $(12,44)$. If the anti-tumor effect of pasireotide is partly mediated via SST5, it suggests that silent corticotroph pituitary tumors may not be good candidates for pasireotide treatment, since only 2 out of the 22 patients in our cohort with silent tumors expressed SST5. These results are in agreement with the lower level of SST5 mRNA found in silent corticotroph tumors in comparison to functioning corticoticotroph tumors that was reported in a previous study (19). On the contrary, SST5 expression was present in 8 of the 13 patients with a functioning macro-corticotroph tumor in our cohort, suggesting that those tumors are more likely to respond to pasireotide. This result is interesting, since macroadenomas associated with Cushing's disease present both a lower rate of remission as well as a higher rate of recurrence $(47,48)$.

In published studies consisting of 11 and 20 patients with silent corticotroph tumors, somatic mutations of USP8 were found in $0 \%$ to $20 \%$ of those tumors (25, $49)$. In contrast, USP8 mutations were found in 24 to $62 \%$ of functioning corticotroph tumors $(21,23,24,25$, $26,27,28)$, with a higher level of SST5 expression in 
USP8mut tumors (21), which is consistent with the results of our study. However, unlike previous findings, mutations in our cohort were not statistically associated with female gender $(21,23,25,50)$ and no differences were found for the age at diagnosis or the tumor size $(21,24,25)$. The USP8 gene encodes a protein with a deubiquitinase activity, which inhibits the degradation of the EGF receptor (EGFR). The activity of USP8 is regulated by the 14-3-3 protein, and all known mutations are found in exon 14, within or close to the 14-3-3 protein binding motif (715-720). Among the mutations found in our cohort, five were previously known mutations (Ser719del, Pro720Arg, Ser718Cys, Ser718Pro and Pro720-Gln724del) (21, 25, 51, 52, 53). Novel mutations were found in two patients, one adjacent to the binding motif (Asp721Glu) in one patient and two mutations in the other patient (Ser719_Gln724delinsLeu and Asn741Asp). The presence of double USP8 mutations in the same patient has already been reported $(28,54)$. In our case, apart from the mutation affecting the 14-3-3 protein biding motif (Ser719_Gln724delinsLeu), the functional impact of the other mutation is difficult to assess. Previous studies have found a greater likelihood of surgical remission (23) as well as a higher risk of recurrence of Cushing's disease (24) in USP8mut tumors, while in our study no difference was found between functioning tumors with or without mutations in terms of tumor grade. IHC for SSTR5 is not routinely performed during histopathological analysis of pituitary tumors. The presence of USP8 mutations, frequently associated with positive SSTR5 expression, could be used as a marker to predict SSTR5 expression and then response to pasireotide treatment. However, such molecular analyses are more costly to perform than immunohistochemistry.

This study has several limits, such as its retrospective nature and the presence of missing data. The number of patients studied, which may seem small, can be explained by the rarity of corticotroph pituitary tumor. Response to pasireotide could be studied only on a small number of patients.

In conclusion, SST5 expression and USP8 mutations are more frequently found in functioning corticotroph tumors. We did not identify clinical predictive marker of SST5 expression, except for the association with functioning tumors and patient gender. The value of SST5 expression as a theranostic marker of response to pasireotide by corticotroph tumors should be the subject of future studies on a larger prospective cohort and may represent a new avenue for personalized therapy.

\section{Supplementary materials}

This is linked to the online version of the paper at https://doi.org/10.1530/ EC-20-0035.

\section{Declaration of interest}

Gérald Raverot received investigator-initiated research grants from Novartis and Ipsen, speaker's fees from Ipsen Pharma, Novartis Pharma, Pfizer Inc. and consulting fees from Novartis. Alexandre Vasiljevic received research grants from Novartis. Emmanuel Jouanneau received speaker's fees from Novartis Pharma and Baxter. Francoise Borson-Chazot received speaker's fees from Novartis Pharma, Novo Nordisk and consulting fees from Novartis, Ipsen, Pfizer Inc, Novo Nordisk and ESAI. Hélène Lasolle received speaker's fees from Novartis Pharma. The other authors have nothing to disclose.

\section{Funding}

This research did not receive any specific grant from any funding agency in the public, commercial or not-for-profit sector.

\section{Acknowledgements}

This paper was revised by an independent scientific English languageediting service.

\section{References}

1 Ntali G, Grossman A \& Karavitaki N. Clinical and biochemical manifestations of Cushing's. Pituitary 201518 181-187. (https://doi. org/10.1007/s11102-014-0631-4)

2 van Haalen FM, Broersen LHA, Jorgensen JO, Pereira AM \& Dekkers OM. Management of endocrine disease: mortality remains increased in Cushing's disease despite biochemical remission: a systematic review and meta-analysis. European Journal of Endocrinology 2015172 R143-R149. (https://doi.org/10.1530/EJE-14-0556)

3 Sharma ST, Nieman LK \& Feelders RA. Comorbidities in Cushing's disease. Pituitary 201518 188-194. (https://doi.org/10.1007/s11102 015-0645-6)

4 Guttenberg KB, Mayson SE, Sawan C, Kharlip J, Lee JY, MartinezLage M, Loevner LA, Ewanichak J, Grady MS \& Snyder PJ. Prevalence of clinically silent corticotroph macroadenomas. Clinical Endocrinology 201685 874-880. (https://doi.org/10.1111/cen.13146)

5 Raverot G, Wierinckx A, Jouanneau E, Auger C, Borson-Chazot F, Lachuer J, Pugeat M \& Trouillas J. Clinical, hormonal and molecular characterization of pituitary ACTH adenomas without (silent corticotroph adenomas) and with Cushing's disease. European Journal of Endocrinology 2010163 35-43. (https://doi.org/10.1530/EJE-100076)

6 Pivonello R, De Leo M, Cozzolino A \& Colao A. The treatment of Cushing's disease. Endocrine Reviews 201536 385-486. (https://doi. org/10.1210/er.2013-1048)

7 Nieman LK, Biller BMK, Findling JW, Murad MH, Newell-Price J, Savage MO, Tabarin A \& Endocrine Society. Treatment of Cushing's syndrome: an Endocrine Society clinical practice guideline. Journal of Clinical Endocrinology and Metabolism 2015100 2807-2831. (https:// doi.org/10.1210/jc.2015-1818)

8 Dallapiazza RF, Oldfield EH \& Jane JA. Surgical management of Cushing's disease. Pituitary 201518 211-216. (https://doi. org/10.1007/s11102-015-0646-5)

9 Petersenn S \& Fleseriu M. Pituitary-directed medical therapy in Cushing's disease. Pituitary 201518 238-244. (https://doi. org/10.1007/s11102-015-0639-4)

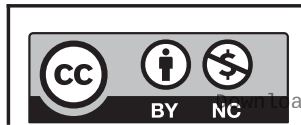

This work is licensed under a Creative Commons Attribution-NonCommercial 4.0 International License. ded from Bioscientifica.com at 04/26/2023 04:58:35AM 
10 Cuevas-Ramos D, Lim DST \& Fleseriu M. Update on medical treatment for Cushing's disease. Clinical Diabetes and Endocrinology 20162 16. (https://doi.org/10.1186/s40842-016-0033-9)

11 van der Hoek J, Lamberts SWJ \& Hofland LJ. The role of somatostatin analogs in Cushing's disease. Pituitary 20047 257-264. (https://doi. org/10.1007/s11102-005-1404-x)

12 Batista DL, Zhang X, Gejman R, Ansell PJ, Zhou Y, Johnson SA, Swearingen B, Hedley-Whyte ET, Stratakis CA \& Klibanski A. The effects of SOM230 on cell proliferation and adrenocorticotropin secretion in human corticotroph pituitary adenomas. Journal of Clinical Endocrinology and Metabolism 200691 4482-4488. (https:// doi.org/10.1210/jc.2006-1245)

13 Colao A, Petersenn S, Newell-Price J, Findling JW, Gu F, Maldonado M, Schoenherr U, Mills D, Salgado LR, Biller BM, et al. A 12-month phase 3 study of pasireotide in Cushing's disease. New England Journal of Medicine 2012366 914-924. (https://doi. org/10.1056/NEJMoa1105743)

14 Lacroix A, Gu F, Gallardo W, Pivonello R, Yu Y, Witek P, Boscaro M, Salvatori R, Yamada M, Tauchmanova L, et al. Efficacy and safety of once-monthly pasireotide in Cushing's disease: a 12 month clinical trial. Lancet: Diabetes and Endocrinology 20186 17-26. (https://doi. org/10.1016/S2213-8587(17)30326-1)

15 Petersenn S, Salgado LR, Schopohl J, Portocarrero-Ortiz L, Arnaldi G, Lacroix A, Scaroni C, Ravichandran S, Kandra A \& Biller BMK. Longterm treatment of Cushing's disease with pasireotide: 5 -year results from an open-label extension study of a phase III trial. Endocrine 201757 156-165. (https://doi.org/10.1007/s12020-017-1316-3)

16 Iacovazzo D, Carlsen E, Lugli F, Chiloiro S, Piacentini S, Bianchi A, Giampietro A, Mormando M, Clear AJ, Doglietto F, et al. Factors predicting pasireotide responsiveness in somatotroph pituitary adenomas resistant to first-generation somatostatin analogues: an immunohistochemical study. European Journal of Endocrinology 2016 174 241-250. (https://doi.org/10.1530/EJE-15-0832)

17 Hofland LJ, van der Hoek J, Feelders R, van Aken MO, van Koetsveld PM, Waaijers M, Sprij-Mooij D, Bruns C, Weckbecker G, de Herder WW, et al. The multi-ligand somatostatin analogue SOM230 inhibits ACTH secretion by cultured human corticotroph adenomas via somatostatin receptor type 5. European Journal of Endocrinology 2005152 645-654. (https://doi.org/10.1530/eje.1.01876)

18 Miller GM, Alexander JM, Bikkal HA, Katznelson L, Zervas NT \& Klibanski A. Somatostatin receptor subtype gene expression in pituitary adenomas. Journal of Clinical Endocrinology and Metabolism 199580 1386-1392. (https://doi.org/10.1210/jcem.80.4.7714115)

19 Tateno T, Kato M, Tani Y, Oyama K, Yamada S \& Hirata Y. Differential expression of somatostatin and dopamine receptor subtype genes in adrenocorticotropin (ACTH)-secreting pituitary tumors and silent corticotroph adenomas. Endocrine Journal 200956 579-584. (https:// doi.org/10.1507/endocrj.k08e-186)

20 Chinezu L, Vasiljevic A, Jouanneau E, François P, Borda A, Trouillas J \& Raverot G. Expression of somatostatin receptors, SSTR2A and SSTR5, in 108 endocrine pituitary tumors using immunohistochemical detection with new specific monoclonal antibodies. Human Pathology 201445 71-77. (https://doi. org/10.1016/j.humpath.2013.08.007)

21 Hayashi K, Inoshita N, Kawaguchi K, Ibrahim Ardisasmita A, Suzuki H, Fukuhara N, Okada M, Nishioka H, Takeuchi Y, Komada M, et al. The USP8 mutational status may predict drug susceptibility in corticotroph adenomas of Cushing's disease. European Journal of Endocrinology 2016 174 213-226. (https://doi.org/10.1530/EJE-15-0689)

22 Fuchs TL, Sioson L, Sheen A, Clarkson A \& Gill AJ. Immunohistochemical expression of somatostatin receptors SSTR2A and SSTR5 in 299 pituitary adenomas. Pathology $201850472-474$. (https://doi.org/10.1016/j.pathol.2017.10.024)

23 Losa M, Mortini P, Pagnano A, Detomas M, Cassarino MF \& Pecori Giraldi F. Clinical characteristics and surgical outcome in USP8mutated human adrenocorticotropic hormone-secreting pituitary adenomas. Endocrine 201963 240-246. (https://doi.org/10.1007/ s12020-018-1776-0)

24 Albani A, Pérez-Rivas LG, Dimopoulou C, Zopp S, Colón-Bolea P, Roeber S, Honegger J, Flitsch J, Rachinger W, Buchfelder M, et al. The USP8 mutational status may predict long-term remission in patients with Cushing's disease. Clinical Endocrinology 201889 454-458. (https://doi.org/10.1111/cen.13802)

25 Perez-Rivas LG, Theodoropoulou M, Ferraù F, Nusser C, Kawaguchi K, Stratakis CA, Faucz FR, Wildemberg LE, Assié G, Beschorner R, et al. The gene of the ubiquitin-specific protease 8 is frequently mutated in adenomas causing Cushing's disease. Journal of Clinical Endocrinology and Metabolism 2015100 E997-E1004. (https://doi.org/10.1210/ jc.2015-1453)

26 Faucz FR, Tirosh A, Tatsi C, Berthon A, Hernández-Ramírez LC, Settas N, Angelousi A, Correa R, Papadakis GZ, Chittiboina P, et al. Somatic USP8 gene mutations are a common cause of pediatric Cushing disease. Journal of Clinical Endocrinology and Metabolism 2017 102 2836-2843. (https://doi.org/10.1210/jc.2017-00161)

27 Ma ZY, Song ZJ, Chen JH, Wang YF, Li SQ, Zhou LF, Mao Y, Li YM, Hu RG, Zhang ZY, et al. Recurrent gain-of-function USP8 mutations in Cushing's disease. Cell Research 201525 306-317. (https://doi. org/10.1038/cr.2015.20)

28 Reincke M, Sbiera S, Hayakawa A, Theodoropoulou M, Osswald A, Beuschlein F, Meitinger T, Mizuno-Yamasaki E, Kawaguchi K, Saeki Y, et al. Mutations in the deubiquitinase gene USP8 cause Cushing's disease. Nature Genetics 201547 31-38. (https://doi.org/10.1038/ ng.3166)

29 Trouillas J, Roy P, Sturm N, Dantony E, Cortet-Rudelli C, Viennet G, Bonneville JF, Assaker R, Auger C, Brue T, et al. A new prognostic clinicopathological classification of pituitary adenomas: a multicentric case-control study of 410 patients with 8 years postoperative follow-up. Acta Neuropathologica 2013126 123-135. (https://doi.org/10.1007/s00401-013-1084-y)

30 Chanson P, Raverot G, Castinetti F, Cortet-Rudelli C, Galland F, Salenave S \& French Endocrinology Society non-functioning pituitary adenoma work-group. Management of clinically nonfunctioning pituitary adenoma. Annales d'Endocrinologie 201576 239-247. (https://doi.org/10.1016/j.ando.2015.04.002)

31 Colao A, Bronstein MD, Freda P, Gu F, Shen CC, Gadelha M, Fleseriu M, van der Lely AJ, Farrall AJ, Hermosillo Reséndiz K, et al. Pasireotide versus octreotide in acromegaly: a head-to-head superiority study. Journal of Clinical Endocrinology and Metabolism 201499 791-799. (https://doi.org/10.1210/jc.2013-2480)

32 Hofland LJ, van der Hoek J, van Koetsveld PM, de Herder WW, Waaijers M, Sprij-Mooij D, Bruns C, Weckbecker G, Feelders R, van der Lely AJ, et al. The novel somatostatin analog SOM230 is a potent inhibitor of hormone release by growth hormone- and prolactinsecreting pituitary adenomas in vitro. Journal of Clinical Endocrinology and Metabolism 200489 1577-1585. (https://doi.org/10.1210/ jc.2003-031344)

33 Gatto F, Feelders RA, Franck SE, van Koetsveld PM, Dogan F, Kros JM, Neggers SJCMM, van der Lely AJ, Lamberts SWJ, Ferone D, et al. In vitro head-to-head comparison between octreotide and pasireotide in GH-secreting pituitary adenomas. Journal of Clinical Endocrinology and Metabolism 2017102 2009-2018. (https://doi.org/10.1210/jc.201700135)

34 Lasolle H, Vasiljevic A, Borson-Chazot F \& Raverot G. Pasireotide: a potential therapeutic alternative for resistant prolactinoma. Annales d'Endocrinologie 201980 84-88. (https://doi.org/10.1016/j. ando.2018.07.013)

35 Coopmans EC, van Meyel SWF, Pieterman KJ, van Ipenburg JA, Hofland LJ, Donga E, Daly AF, Beckers A, Van der Lely AJ \& Neggers SJCMM. Excellent response to pasireotide therapy in an aggressive and dopamine-resistant prolactinoma. European Journal of Endocrinology 2019181 K21-K27. (https://doi.org/10.1530/EJE-190279) https://ec.bioscientifica.com https://doi.org/10.1530/EC-20-0035 (c) 2020 The authors Published by Bioscientifica Ltd
This work is licensed under a Creative Commons Attribution-NonCommercial 4.0 International License. ded from Bioscientifica.com at 04/26/2023 04:58:35AM 
36 Raverot G, Vasiljevic A, Jouanneau E \& Lasolle H. Excellent response to pasireotide therapy in an aggressive and dopamine-resistant prolactinoma - commentary. European Journal of Endocrinology 2019 181 C1-C3. (https://doi.org/10.1530/EJE-19-0359)

37 Behling F, Honegger J, Skardelly M, Gepfner-Tuma I, Tabatabai G, Tatagiba M \& Schittenhelm J. High expression of somatostatin receptors $2 \mathrm{~A}, 3$, and 5 in corticotroph pituitary adenoma. International Journal of Endocrinology 20182018 1763735. (https:// doi.org/10.1155/2018/1763735)

38 Gatto F, Feelders RA, van der Pas R, Kros JM, Waaijers M, SprijMooij D, Neggers SJCMM, van der Lelij AJ, Minuto F, Lamberts SWJ, et al. Immunoreactivity score using an anti-sst2A receptor monoclonal antibody strongly predicts the biochemical response to adjuvant treatment with somatostatin analogs in acromegaly. Journal of Clinical Endocrinology and Metabolism 201398 E66-E71. (https:// doi.org/10.1210/jc.2012-2609)

39 Muhammad A, Coopmans EC, Gatto F, Franck SE, Janssen JAMJL, van der Lely AJ, Hofland LJ \& Neggers SJCMM. Pasireotide responsiveness in acromegaly is mainly driven by somatostatin receptor subtype 2 expression. Journal of Clinical Endocrinology and Metabolism 2019104 915-924. (https://doi.org/10.1210/jc.2018-01524)

40 Theodoropoulou M \& Stalla GK. Somatostatin receptors: from signaling to clinical practice. Frontiers in Neuroendocrinology 201334 228-252. (https://doi.org/10.1016/j.yfrne.2013.07.005)

41 van der Hoek J, Waaijers M, van Koetsveld PM, Sprij-Mooij D, Feelders RA, Schmid HA, Schoeffter P, Hoyer D, Cervia D, Taylor JE, et al. Distinct functional properties of native somatostatin receptor subtype 5 compared with subtype 2 in the regulation of ACTH release by corticotroph tumor cells. American Journal of Physiology: Endocrinology and Metabolism 2005289 E278-E287. (https://doi. org/10.1152/ajpendo.00004.2005)

42 Gatto F, Arvigo M, Amarù J, Campana C, Cocchiara F, Graziani G, Bruzzone E, Giusti M, Boschetti M \& Ferone D. Cell specific interaction of pasireotide: review of preclinical studies in somatotroph and corticotroph pituitary cells. Pituitary 201922 89-99. (https://doi.org/10.1007/s11102-018-0926-y)

43 Lesche S, Lehmann D, Nagel F, Schmid HA \& Schulz S. Differential effects of octreotide and pasireotide on somatostatin receptor internalization and trafficking in vitro. Journal of Clinical Endocrinology and Metabolism 200994 654-661. (https://doi. org/10.1210/jc.2008-1919)

44 Murasawa S, Kageyama K, Sugiyama A, Ishigame N, Niioka K, Suda T \& Daimon M. Inhibitory effects of SOM230 on adrenocorticotropic hormone production and corticotroph tumor cell proliferation in vitro and in vivo. Molecular and Cellular Endocrinology 2014394 37-46. (https://doi.org/10.1016/j.mce.2014.07.001)

45 Shimon I, Rot L \& Inbar E. Pituitary-directed medical therapy with pasireotide for a corticotroph macroadenoma: pituitary volume reduction and literature review. Pituitary 201215 608-613. (https:// doi.org/10.1007/s11102-012-0427-3)

46 Simeoli C, Auriemma RS, Tortora F, De Leo M, Iacuaniello D, Cozzolino A, De Martino MC, Pivonello C, Mainolfi CG, Rossi R, et al. The treatment with pasireotide in Cushing's disease: effects of long-term treatment on tumor mass in the experience of a single center. Endocrine 201550 725-740. (https://doi.org/10.1007/s12020015-0557-2)

47 Alexandraki KI, Kaltsas GA, Isidori AM, Storr HL, Afshar F, Sabin I, Akker SA, Chew SL, Drake WM, Monson JP, et al. Long-term remission and recurrence rates in Cushing's disease: predictive factors in a single-centre study. European Journal of Endocrinology 2013168 639-648. (https://doi.org/10.1530/EJE-12-0921)

48 Valassi E, Biller BMK, Swearingen B, Pecori Giraldi F, Losa M, Mortini P, Hayden D, Cavagnini F \& Klibanski A. Delayed remission after transsphenoidal surgery in patients with Cushing's disease. Journal of Clinical Endocrinology and Metabolism 201095 601-610. (https://doi.org/10.1210/jc.2009-1672)

49 Bujko M, Kober P, Boresowicz J, Rusetska N, Paziewska A, Dabrowska M, Piascik A, Pekul M, Zielinski G, Kunicki J, et al. USP8 mutations in corticotroph adenomas determine a distinct gene expression profile irrespective of functional tumour status. European Journal of Endocrinology 2019181 615-627. (https://doi.org/10.1530/ EJE-19-0194)

50 Wanichi IQ, de Paula Mariani BM, Frassetto FP, Siqueira SAC, de Castro Musolino NR, Cunha-Neto MBC, Ochman G, Cescato VAS, Machado MC, Trarbach EB, et al. Cushing's disease due to somatic USP8 mutations: a systematic review and meta-analysis. Pituitary 201922 435-442. (https://doi.org/10.1007/s11102-01900973-9)

51 Perez-Rivas LG \& Reincke M. Genetics of Cushing's disease: an update. Journal of Endocrinological Investigation 201639 29-35. (https://doi.org/10.1007/s40618-015-0353-0)

52 Pérez-Rivas LG, Theodoropoulou M, Puar TH, Fazel J, Stieg MR, Ferraù F, Assié G, Gadelha MR, Deutschbein T, Fragoso MC, et al. Somatic USP8 mutations are frequent events in corticotroph tumor progression causing Nelson's tumor. European Journal of Endocrinology 2018178 57-63. (https://doi.org/10.1530/EJE-17-0634)

53 Cassarino MF, Ambrogio AG, Cassarino A, Terreni MR, Gentilini D, Sesta A, Cavagnini F, Losa M \& Pecori Giraldi F. Gene expression profiling in human corticotroph tumours reveals distinct, neuroendocrine profiles. Journal of Neuroendocrinology 201830 e12628. (https://doi.org/10.1111/jne.12628)

54 Ballmann C, Thiel A, Korah HE, Reis AC, Saeger W, Stepanow S, Köhrer K, Reifenberger G, Knobbe-Thomsen CB, Knappe UJ, et al. USP8 mutations in pituitary Cushing adenomas-targeted analysis by next-generation sequencing. Journal of the Endocrine Society 20182 266-278. (https://doi.org/10.1210/js.2017-00364)

Received in final form 17 February 2020

Accepted 25 February 2020

Accepted Manuscript published online 26 February 2020 https://ec.bioscientifica.com https://doi.org/10.1530/EC-20-0035 (c) 2020 The authors Published by Bioscientifica Ltd

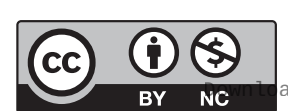

This work is licensed under a Creative Commons Attribution-NonCommercial 4.0 International License. ded from Bioscientifica.com at 04/26/2023 04:58:35AM 